\title{
Üniversite Öğrencilerinin Ruminatif Düşünme Biçimlerinin ve Sosyal İyi Olma Düzeylerinin Duygusal Zekâ Düzeyleri ile İlişkisi' ${ }^{1}$
}

\author{
DOI: 10.26466/opus.568178
}

\author{
* \\ Zeynep Lale* - Fikret Gülaçț ${ }^{* *}$ \\ * Ögretmen, Erzincan Anadolu Lisesi, Erzincan / Türkiye \\ E-Posta: zeyneppdr91@hotmail.com \\ ORCID: 0000-0002-9522-6859 \\ ** Doç. Dr. Erzincan Binali Yıldırım Üniversitesi, Eğitim Fakültesi, Erzincan/ Türkiye \\ E-Posta: fikretgul@hotmail.com \\ ORCID: 0000-0002-3200-1994
}

\section{Öz}

$B u$ araştırma, üniversite öğrencilerinin ruminatif düşünme biçimleri ve sosyal iyi olma düzeylerinin duygusal zekâ düzeyleri ile ilişkisinin incelenmesi amacıyla yapılmıştır. Araştırmanın çalışma grubunu 2017-2018 akademik yılında Erzincan Binali Yıldırım Üniversitesinin 7 farkl fakültesinde lisans programlarında öğrenim görmekte olan; olasılı̆̆a dayalı küme örnekleme yöntemiyle belirlenen 670 öğrenci oluşturmaktadır. Bu öğrencilerin 244'ü erkek (\%36.4), 426'sı (\%63.6) ise kadındır. Araştırma sonucunda ruminatif düşünme biçimi puanı cinsiyete, algzlanan gelir düzeyine, algzlanan anne baba tutumuna göre anlamlı farklılık gösterirken algılanan akademik başarıya göre anlamlı bir farklılık göstermemiştir. Üniversite öğrencilerinin sosyal iyi olma düzeylerinde cinsiyete, algılanan gelir düzeyine ve algzlanan akademik başarıya göre farklıllk göstermediği, ancak algllanan anne baba tutumuna göre anlaml farklılı olduğu bulunmuştur. Toplam duygusal zekâ puanının cinsiyete, algzlanan gelir düzeyine, algılanan akademik başarlya ve algılanan anne baba tutumuna göre farklllık göstermediği bulunmuştur. Ayrıca üniversite öğrencilerinin ruminatif düşünme biçimleri ve sosyal iyi olma düzeylerinin duygusal zekâ düzeyleri ile arasında negatif yönde anlamlı bir ilişkisi olduğu görülmektedir.

Anahtar Kelimeler: Ruminatif Düşünme Biçimi, Sosyal İyi Olma, Duygusal Zekâ.

Bu çalışma 2019 yılında Erzincan Üniversitesi Sosyal Bilimler Enstitüsünde kabul edilmiş yüksek lisans tezinden üretilmiştir. 


\title{
The Relationship Between Ruminative Thought Style and Social Well Being Level of the University Students with the Emotional Intelligence
}

\begin{abstract}
This research has been conducted to investigate the relationship between university students' ruminative thought and social well-being levels with the emotional intelligence. The study group consists of 670 students who were determined by cluster sampling method and studying in the undergraduate programs of the 7 different faculties of Erzincan Binali Yildirim University in the 2017-2018 academic year. 244 of these students (\%36.4) were male and 426 of the rest (63.6\%) were female. As a result of the study, ruminative thought style score showed significant difference according to gender, perceived income level, perceived parental attitude, on the other hand it showed no significant difference according to perceived academic success. It was found that there was no significant difference in terms of gender, perceived income level and perceived academic success in social well-being of university students in comparison with perceived parental attitude. It was found that total emotional intelligence score did not showed difference according to gender, perceived income level, perceived academic achievement and perceived parental attitude. In addition, among the ruminative thought styles and social well-being with emotional intelligence have seen a significant relationship in the negative direction.
\end{abstract}

Keywords: Ruminative Thought Style, Social Well-Being, Emotional Intelligence. 


\section{Giriş}

Geçmiş zamanlardan bu yana zekâ kavramı bireylerin yeteneklerinin açığa çıkmasında önemli bir faktör olarak ele alınmıştır. Ayrıca psikolojide bireyin duygusal boyutu da yoğun bir şekilde üzerinde durulan bir konudur. Bu bağlamda araştırmacılar tarafından zekâ ve duygu arasındaki ilişki ve bu iki kavramın etkileşiminin önemi vurgulanmıştır. Goleman'a (2017, s.62) göre duygusal zekâ; "kendini harekete geçirebilme, aksiliklere rağmen yoluna devam edebilme, dürtüleri kontrol ederek tatmini erteleyebilme, ruh halini düzenleyebilme, sıkıntıların düşünmeyi engellemesine izin vermeme, kendini başkasının yerine koyabilme ve umut besleyebilmektir". Bireylerin duygusal zekâlarını etkin bir şekilde kullanmaları ile başarının da devamında geleceği ön görülmektedir. Duygusal zekâsı yüksek olan bireyler kendilerini tanıyan, ihtiyaçlarını bilen, güçlü ve zayıf yanlarının farkında olan ve duygularını yöneterek etkili ve sağlıklı kararlar alabilen bireyler olarak nitelendirilirler (Çetinkaya, 2017).

Petrides ve Furnham (2001) tarafından duygusal zekâ öznel iyi oluş, öz kontrol, duygusallık ve sosyallik olarak dört alt boyutta incelenmiştir. Bu alt boyutlar özetlenecek olursa;

- İyi oluş boyutu; bireyin genel anlamda hayatından memnun olması, birtakım iyi özelliklere sahip olması, kişisel donanım ve güçlü yönlerin farkında olması, pozitif bakabilmesi ve genel olarak hayatta işlerin yolunda gideceğine inanması

- Öz kontrol boyutu; bireyin duyguların kontrol etmesi, karar verebilmesi yahut değiştirmesi, stresle başa edebilmesi

- Duygusallık boyutu; bireyin hislerini ayırt edebilmesi, yakın çevresine duyguları gösterebilmesi, sıklıkla hisleri düşünebilmesi, yakın kişilerle bağ kurabilmesi

- Sosyallik boyutu; bireyin diğer insanlarla baş edebilmesi, haklarını savunabilmesi, diğer insanların duyguların etkileyebilmesi, tartışma gibi durumlarda gösterilen tutumları olarak nitelendirilir.

Duygusal zekânın literatüre girmesi ile konu oldukça ilgi çekmiş ve pek çok model geliştirilmiştir. Bu modeller yetenek ve karma modelleri olmak üzere iki başlık altında incelenmektedir. Bu modeller duygusal zekânın farklı noktaları üzerinde dursalar da bu modellerin her ikisi de duygusal zekânın sonradan öğrenilip geliştirilmesi konusunda fikir birliği 
içindedir (İnci, 2014). Ayrıca temelde çıkış noktaları aynı olsa da ikisi de çeşitli kişilik özelliklerinden oluşur (Ulutaş, 2005).

\section{Tablo 1. Duygusal Zekâ Modelleri Temel Boyutları(Doğan ve Şahin, 2007)}

\begin{tabular}{|c|c|c|}
\hline $\begin{array}{l}\text { Bar-On } \\
\text { Modeli } \\
(1997)\end{array}$ & $\begin{array}{l}\text { 1.Kişisel Beceriler: Kendine güven-Duygusal benlik bilinci - Bağımsızlık- } \\
\text { Kendine sayg1- Kendini gerçekleştirme. } \\
\text { 2.Kişilerarası Beceriler: Bireyler arası ilişkiler-Empati-Sosyal sorumluluk. } \\
\text { 3. Uyumluluk Boyutu: Problem çözme- Esneklik Gerçeklik Testi. } \\
\text { 4. Stresle Başa Çıkma Boyutu: Stres toleransı- Dürtü kontrolü. } \\
\text { 5. Genel Ruh Durumu: İyimserlik-Mutluluk. }\end{array}$ & \multirow{3}{*}{$\begin{array}{l}\text { Karma } \\
\text { Model }\end{array}$} \\
\hline $\begin{array}{l}\text { Goleman } \\
(2017)\end{array}$ & $\begin{array}{l}\text { 1-Kişisel Yeterlilik: Özbilincin içinde duygusal bilinç, öz değerlendirme, } \\
\text { özgüven- Kendine Yön Vermenin içinde özdenetim, güvenilirlik, uyumluluk } \\
\text { vicdanlılık, yenilikçilik)- Motivasyonun içinde başarma güdüsü, bağlılık, } \\
\text { inisiyatif, iyimserlik. } \\
\text { 2. Sosyal Yeterlilik: Empati kavramı içinde; başkalarını anlamak, başkalarını } \\
\text { geliştirmek, hizmete yönelik olmak, politik bilinç, çeşitlilikten yararlanma, } \\
\text { politik bilinç- Sosyal becerilerin içinde etki, iletişim, çatışma yönetimi, liderlik, } \\
\text { değişim katalizörlüğü, bağ kurmak, işbirliği ve dayanışma, takım yetenekleri. }\end{array}$ & \\
\hline $\begin{array}{l}\text { Cooper } \\
\text { ve Sawaf } \\
(1997)\end{array}$ & $\begin{array}{l}\text { 1.Duyguları Öğrenme köşe taşı: Duygusal dürüstlük- Duygusal enerji- Duy- } \\
\text { gusalal geribildirim- Pratik sezgi. } \\
\text { 2. Duygusal Zindelik köşe taşı: Öz varlık- Güven Çemberi-Yapıcı hoşnutsu- } \\
\text { zluk- Esneklik ve yenileme. } \\
\text { 3. Duygusal Derinlik köşe taşı: Özgün potansiyel ve amaç- Dürüstlüğü } \\
\text { yaşamak- Adanmışlık- Yetki olmadan etki. } \\
\text { 4. Duygusal Simya köşe taşı: Sezgisel akış -Düşünsel zaman değişimi- Fırsatı } \\
\text { sezinlemek-Geleceği yaratmak. }\end{array}$ & \\
\hline $\begin{array}{l}\text { Mayer } \\
\text { ve } \\
\text { Salovey } \\
\text { Modeli } \\
(1997)\end{array}$ & $\begin{array}{l}\text { 1-Duyguları Algılama, Değerlendirme ve Ifade Etme: Kendisinin ve } \\
\text { başkalarının duygularını anlamak ve ifade etmek- Duyguların tam ifade } \\
\text { edilmesi ve gereksinimlerin iletilmesi- Farklı duygusal ifadeleri ayırt ede- } \\
\text { bilmek. } \\
\text { 2- Duyguların Kullanımı: Duyguların dikkati yöneterek düşünmeyi sağla- } \\
\text { ması- Ruh halinin bireyin algılamasının değiştirmesi- farklı bakış açlarını } \\
\text { anlamak. } \\
\text { 3- Duyguyu Anlamak ve Muhakeme Etmek: Duyguları nitelendirmek ve farklı } \\
\text { duygular ile bu duyguların anlamları arasındaki ilişkiyi tanımlamak- } \\
\text { Karmaşık duyguları yorumlamak ve farklı duyguların bileşimini anlamak ile } \\
\text { duygular arasındaki geçişleri anlamak Duyguların içeriğini ve karşılıklı } \\
\text { ilişkilerinin sahip olduğu bilgiyi anlamak. } \\
\text { 4. Duyguyu Yönetme ve Düzenleme: Hoş ve hoş olmayan duygulara açık } \\
\text { olabilmek, duyguları ayırt edebilmek - Kendinin ve başkalarının duygularını } \\
\text { yönetebilmek-Olumsuz duyguların etkisini azaltarak ve olumlu duyguların } \\
\text { etkisini artırabilmek. }\end{array}$ & $\begin{array}{l}\text { Yetenek } \\
\text { Modeli }\end{array}$ \\
\hline
\end{tabular}

İnsanlı tarihi boyunca filozoflar tarafından bireyin mutluluk kavramı, iyi hissetmesi ve yüksek motivasyonu merak konusu olmuştur. 
Ancak psikoloji literatüründe mutsuzluk derinlemesine işlenirken pozitif iyi oluş görmezden gelinen bir unsur olmuştur (Diener, 1984).

Son zamanlarda yapılan çalışmaların ruhsal hastalıklardan ziyade pozitif ruh sağlığına, mutluluk ve iyi olma temellerine odaklandığı görülmektedir. İyi oluş bireyin bilişsel ve duyuşsal olarak kendi yaşamını değerlendirmesidir. Bireyin bu değerlendirmesinin sonunda ulaştığı sonuç iyi oluş durumu hakkında bilgi vermektedir (Diener, 2000). İyi oluşun içinde bulunan kavramlar ise duygusal iyi oluş, psikolojik iyi oluş ve sosyal iyi oluştur (Dawson, Singh-Dhesi, 2010: Akt. Şanal Karahan, 2016). Keyes'e (1998) göre; sosyal iyi oluş, iyi olmanın sosyal bir örneğinin evrensel bir tanımı için bir temel oluşturur. Sosyal iyi olul; bireyin durumunu değerlendirmesi ve toplumsal işleyişi ele almasıdır. Keyes'in sosyal iyi oluş modeli iyi oluşun sosyallik yönünü kavramsallaştırır. Bireylerin sosyal yaşamdaki işlevlerinin ne derecede olduğunu gösteren beş boyutta ele alınır. Keyes'in (1998) modeli incelenecek olursa;

Sosyal Kabul: Kendini kabulün sosyal halidir. Diğer bireylere güvenen, üreten ve iyilik yapma yeteneği olan, dünyayı ve toplumu olumlu algılayan; olumsuz yönlerini de kabul edebilen bireyler sosyal kabulü yüksek olan bireylerdir.

Sosyal Gerçekleşme: Toplumun potansiyelini ve ilerlemesini vurgular, toplumun yörüngesini değerlendirir.

Sosyal Katkı: Bireyin toplumdaki önemini değerlendirerek; toplum için değerli bir fert olduğunu düşünmesi ve dünyaya katabileceği değerli bir şeyler olduğuna ilişkin inancını ele alır.

Sosyal Uyum: Sosyal açıdan sağlıklı bireylerin içinde bulundukları dünyaya ilgi duymalarıdır.

Ruh sağlığı kavramı kendi içinde bireyin yaşamının geçmişini, şu anki durumunu ve geleceğini barındırmaktadır. Çoğu insanın geçmişinde, şu anında yaşamış olduğu ya da yaşayacağını ön gördüğü bazen istemeden bazen de isteyerek bireyin bu olumlu ve olumsuz durumları aklına getirdiği 
öngörülmektedir. Bireylerin akıllarına gelen bu düşünceler yer yer bireyin kendini düzenlemesine yardımc olurken yer yer de bireyi yıpratan bir süreç olabilmektedir. Özellikle geleceğe yönelik var olan amaçların sürekli düşünülmesi ilerlemeyi sağlayabilir (Martin ve Tesser, 1996). Fakat geçmişte ve şu anda yaşanan ya da ileride yaşanması beklenen olumsuz olaylara odaklanmak bireyin gündelik yaşantısını, buna bağlı olarak da ruh sağlığını olumsuz yönde etkileyeceği düşünülmektedir. Bireyin var olan problemlerini çözmek için harekete geçmeyip geçmişe sıkışarak içinde bulunduğu duyguların olası neden ve sonuçları hakkında tekrarlayan düşüncelerde bulunması ruminasyon kavramı olarak tanımlanmaktadır (NolenHoeksema, 1987). Ruminasyona yönelik kuramlar incelendiğinde;

Tepki Biçimleri Kuramı: Bu kuramda ruminasyon; bireyin depresyon belirtilerine, bu belirtilerin olası sebep ve sonuçlarına odaklanılmış bir düşünme biçimi olarak ele alınmıştır (Butler ve Nolen-Hoeksema, 1994). NolenHoeksema'ya (2004, s.107-108) göre bu kuramda; bireyin isteği dışında aklına gelen ve kontrol edilemez olarak algılanan zorlayıcı düşünme olan ruminatif düşünme; depresyonu da uzatan bir etkendir.

Amaca Yönelik Ilerleme Kuramı: Amaca yönelik ilerleme kuramı esasında Zeigarnik etkisinin bir örneği olarak nitelendirilebilir. Carver ve Scheier (1990) amaca yönelik ilerleme kuramının esas olarak henüz ulaşılamamış önemli hedefleri tekrarlı olarak düşünmeyi ele aldığını ve hedefe odaklanıldığını ifade eder.

Üzüntü Hakkında Ruminasyon: Bu kuramın öncüleri olan Conway ve arkadaşları (2000; Akt. Luminet, 2004:195-196); ruminasyon kavramına bir fikir olarak odaklanmışlardır. Ruminasyon kavramını bireyin anlık ve şimdiki üzüntüsü ve bu üzüntünün koşulları ile ilgili tekrarlayan düşünceler olarak ele alır. Bu düşünceler olumsuz duygulanımlarla ilişkilidir, iyileştirici bir etkisi yoktur ve diğer bireylerle paylaşılamaz durumdadır.

Strese Tepki Olarak Ruminasyon: Bireyin yaşamış olduğu stresli bir durumun ardından olumsuz çkarımlar yapması ve bunları sürekli düşünmesini ele alır (Alloy, Abramson,Hogan,Whitehouse,Rose,Robinson, Kim ve Lapkin, 2000). 
Benlik Düzenleyici Yürütücü İşlevler Teorisi: Matthews ve Wells'e (1994) göre ruminasyonda genellikle istemli olarak güdüler tetiklenmez, kendi durumu ve hedefi arasındaki tutarsızlık tespit edildiğinde ruminasyon süreci daha da azaltılabilir, böylece var olan durum hakkında süreç yenilenebilir. Bu kuramda ruminasyon durumunda birey duygu odaklı başa çıkma stratejisini kullanarak kendini düzenler ve bu bireyin iç bilişinin ve öz bilgisinin bir ürünü olarak ortaya çkar (Akt. Wells ve Matthews, 2004, s.130).

Yapılan araştırmalar incelendiğinde ruminatif düşünme biçimi, sosyal iyi olma ve duygusal zekâ kavramlarının birlikte kullanıldığı herhangi bir çalışmaya rastlanmamıştır. Bu nedenle üniversite öğrencilerinin ruminatif düşünme biçimleri ve sosyal iyi olma düzeylerinin duygusal zekâ düzeyleri ile ilişkisi adlı konu araştırılması gereken bir konu olarak görülmüştür ve bulguların literatüre katkı sağlayacağı düşünülmektedir.

\section{Yöntem}

Araştırmanın bu bölümünde araştırmanın modeli, evren ve örneklemi, kullanılan veri toplama araçları, veri toplama yöntemi, araştırmacının rolü, verilerin toplanması ve analizi ile ilgili bilgiler yer almaktadır.

\section{Araştırmanın Modeli}

Araştırma genel tarama modellerinden ilişkisel tarama modeli ile gerçekleştirilmiştir. İlişkisel tarama modelleri iki ya da daha çok sayıda değişken arasında birlikte değişim varlığını veya derecesini belirlemeyi amaçlayan araştırma modelleridir (Karasar, 2016, s.114).

\section{Araştırma Grubu}

Araştırma grubu örnekleme tekniği olarak, küme örnekleme tekniği kullanılmıştır. Küme örneklemede evrendeki bütün kümelerin tek tek (bütün elemanlarıyla birlikte) eşit seçilme şansına sahip oldukları örneklemedir (Karasar, 2016, s.152). 
Bu araştırmanın evrenini 2017-2018 akademik yılında 7 farklı fakültede (İktisadi ve İdari Bilimler Fakültesi, Eğitim Fakültesi, Fen Edebiyat Fakültesi, İlahiyat Fakültesi, Hukuk Fakültesi, Mühendislik Fakültesi, Eczacılık Fakültesi) öğrenim gören 11.257 lisans öğrencisi oluşturmaktadır. Araştırma evreninden oluşan 670 kişilik örneklem grubu kolay ulaşılabilir olanlardan seçilmiştir.

Tablo 2. Çalışma Grubunun Yaş Değişkenine Göre Betimleyici İstatistikleri

\begin{tabular}{llll}
\hline Değişken & $\mathrm{N}$ & \multicolumn{1}{c}{$\bar{X}$} & Ss \\
\hline Yaş & 670 & 1,95 \\
\hline
\end{tabular}

Tablo 3 . Çalışma Grubunun Demografik Değişkenlere Göre Dağılımı

\begin{tabular}{|c|c|c|c|}
\hline & & Frekans & Yüzde \\
\hline \multirow[t]{2}{*}{ Cinsiyet } & Kadın & 426 & 63.6 \\
\hline & Erkek & 244 & 36.4 \\
\hline \multirow{7}{*}{ Öğrenim Görülen Fakülte } & Hukuk Fakültesi & 84 & 12,5 \\
\hline & İlahiyat Fakültesi & 115 & 17,2 \\
\hline & İktisadi ve İdari Bilimler Fakültesi & 80 & 11,9 \\
\hline & Eczacilık Fakültesi & 64 & 9,6 \\
\hline & Mühendislik Fakültesi & 87 & 13,0 \\
\hline & Fen Edebiyat Fakültesi & 129 & 19,3 \\
\hline & Eğitim Fakültesi & 111 & 16,6 \\
\hline \multirow[b]{3}{*}{ Algılanan Gelir Düzeyi } & Düşük & 88 & 13,1 \\
\hline & Orta & 552 & 82,4 \\
\hline & Yüksek & 30 & 4,5 \\
\hline \multirow{4}{*}{ Algılanan Anne Baba Tutumu } & İlgisiz & 12 & 1,8 \\
\hline & Otoriter & 76 & 11,3 \\
\hline & Koruyucu & 428 & 63,9 \\
\hline & Demokratik & 154 & 23,0 \\
\hline \multirow{4}{*}{$\begin{array}{l}\text { Algılanan } \\
\text { Düzeyi }\end{array}$} & Düşük & 44 & 6,6 \\
\hline & Orta & 505 & 75,4 \\
\hline & Yüksek & 121 & 18,1 \\
\hline & TOPLAM & 670 & 100,0 \\
\hline
\end{tabular}

\section{Veri Toplama Araçlarn}

Araştırmanın bu bölümünde veri toplama araçlarının adı, niteliği ve geçerlilik- güvenirlik bilgilerine yer verilmiştir. 
Kişisel Bilgi Formu: Araştırmacı tarafından hazırlanan kişisel bilgi formu toplam 6 sorudan oluşmaktadır. Katılımclardan cinsiyet, yaş, fakülte, ailelerinin algılanan gelir düzeyi, anne babanın algılanan tutumu ve öğrencinin şu anki akademik başarı algısı ile ilgili bilgiler bulunmaktadır.

Duygusal Zeka Özelliği Ölçeği-Kısa Formu: Araştırmada kullanılacak "Duygusal Zekâ Özelliği Ölçeği-Kısa Formu (DZÖÖ-KF)" Petrides ve Furnham $(2000,2001)$ tarafından geliştirilmiş, M. Engin Deniz, Esin Özer, Erkan Işık (2013) tarafından Türkçeye uyarlanan geçerliliği ve güvenilirliği daha önceden ispat edilmiş bir ölçektir. 20 maddeden oluşan dört faktörlü bir yapiya sahiptir. Bu dört faktör ise "öznel iyi oluş","özkontrol”,"duygusallık” ve "sosyallik" tir. 7'li likert tipi ölçek şeklindedir. 1 "Kesinlikle Katılmıyorum" cevabını ifade ederken; 7 "Kesinlikle Katılıyorum" cevabını ifade etmektedir. DZÖÖ-KF'nun iç tutarlılık güvenirlik katsayısı için .81, test-tekrar test güvenirlik katsayısı ise .86 'dır. Ölçeğin güvenirlik analizinde ise DZÖÖ-KF'nun Cronbach Alpha katsayıları iyi oluş faktörü için .72, öz kontrol için .70, duygusallık için .66, sosyallik için .70 ve ölçeğin tamamı için .81 olduğu görülmüştür ve bu da hem orijinal formu hem de farklı dillere çevrilmiş olan formlarıla yakın değerlerdir. Ölçek üniversite öğrencilerine uygulanabilir. Ayrıca üniversite öğrencilerinden biraz daha yüksek yaş seviyelerine uygulanabilir niteliktedir. Yapılan bu çalışmada ölçeğin Cronbach Alpha değeri .58 bulunmuştur.

Sosyal İyi Olma Ölçeği: Katılımcıların sosyal iyi olma düzeylerini ölçmek amaciyla (Keyes, 1998) tarafından geliştirilen, özgün adı Social Well being Scale olan bu ölçeğin Türkçe'ye uyarlama çalışması; Akın, Demirci, Çitemel, Sarıçam ve Ocakçı (2013, Mayıs) tarafından yapılmıştır. Ölçek 15 maddeden oluşmaktadır ve 7'li likert tipi ölçek kullanılmıştır. Ölçekte 1, “Kesinlikle Katılmıyorum" ile 7 "Kesinlikle Katılıyorum" anlamlarına gelmektedir.15 maddeden oluşan bu ölçeğin yapı geçerliğinde orijinal formunda olan beş faktörlü yapı Türkçe formunda tek faktörlü olarak uyumlu olduğu bulunmuştur $\left(X^{2}=155.46, \mathrm{sd}=86, \mathrm{p}=.00001\right.$, RMSEA $=.054, \mathrm{GFI}=.93$, AGFI= .90, $\mathrm{SRMR}=.065)$. SİOÖ Türkçe formu için Cronbach Alpha iç tutarlılık güvenirlik katsayısı .64 olarak bulunmuştur (Akın, Demirci, Çitemel, Sarıçam ve Ocakçı, 2013). Yapılan bu çalışmada ölçeğin Cronbach Alpha değeri .53 bulunmuştur. 
Ruminatif Düşünme Biçimi Ölçeği: Özgün adı "Ruminative Thought Style Questionnaire (RTSQ)" olan ölçek; Jay K. Brinker ve David J.A. Dozois tarafından 2009 yılında geliştirilmiş olup Türkçe'ye Hasan Turan Karatepe (2010) tarafından uyarlanmıştır. 20 maddeden oluşur ve 7'li likert tipi kullanılmıştır. Bu likert ölçeğinde 1 "hiç" cevabı olarak nitelendirilirken 7 "çok iyi" cevabını ifade etmektedir. Bu ölçek ruminatif düşünme biçimini tekrarlayıcı, kontrol edilemeyen bir düşünme biçimi olarak ele almaktadır. Güvenirlik çalışmasında korelasyon analizi ile ölçeği iç tutarlılığının yüksek olduğu bulunmuştur (Cronbach Alpha= 0.907). Madde toplam puan korelasyon katsayısının 0.474 (RDBÖ6) ila 0.699 (RDBÖ3) arasında olduğunu ve böylelikle testin tümü ile tutarlılığının olduğu görülmektedir. Ölçeğin testtekrar test korelasyon katsayısı $0.84^{\prime}$ tür ve bu da iki ölçüm arasında güçlü bir ilişkinin olduğunu ifade etmektedir Ölçek tek faktörlüdür. Ayrıca eş zaman ve ayırt edici geçerlilik çalışmasında karşılaştırılan ölçeklerle anlamlı ilişkiler bulunmuştur (Karatepe, 2010). Yapılan bu çalışmada ölçeğin Cronbach Alpha değeri .90 bulunmuştur.

\section{Verilerin Analizi}

Verilerin analizi iki ardışık aşamada gerçekleştirilmiştir. Birinci aşamada veriler eksik değer, aykırı değer, normallik, çoklu değişme açısından incelenmiştir. Diğer bir ifadeyle analizlerin hipotezleri test edilmiştir. Hipotezlerin incelenmesi için ilk aşamada katılımcılardan toplanan veriler hatalı kodlama açısından incelenmiştir. Daha sonra ölçeklerin biri ya da birden fazlasını boş bırakan katılımcıların anketi değerlendirmeye alınmamıştır. İkinci aşamada veriler normal dağılım testine tabi tutularak verilerin homojen dağılım gösterip göstermediğine bakılmıştır. Verilerin analizlerine başlamadan önce verilerin parametrik mi non-parametrik mi olduğunu belirlenmiştir. Bu bağlamda uygun istatistiksel analizler seçilmiştir. Verilerin parametrik olabilmesi için normal dağılıma sahip olması beklenmektedir. 
Tablo 4. Ölçme Araçlarına İlişkin Kolmogorov-Smirnov ve Shapiro Wilk Testleri

\begin{tabular}{|c|c|c|c|c|c|c|}
\hline & \multicolumn{3}{|c|}{ Kolmogorov-Smirnov } & \multicolumn{3}{|c|}{ Shapiro- Wilk } \\
\hline Ölçek & $\mathrm{z}$ & $\mathrm{df}$ & $\mathrm{p}$ & $\mathrm{z}$ & $\mathrm{df}$ & $\mathrm{p}$ \\
\hline RDBÖ & 051 & 666 & 000 & ,980 & 666 &, 000 \\
\hline DZÖÖ-KF & ,044 & 666 & ,004 & ,994 & 666 & ,007 \\
\hline SİOÖ & ,045 & 666 & 003 & ,990 & 666 & ,000 \\
\hline
\end{tabular}

Yapılmış olan normallik analizi olan Kolmogorov-Smirnov ve ShapiroWilk analizi sonuçlarına göre elde edilen veriler normal dağılmadığı için verilerin analizinde non-parametrik testler kullanılmıştır. Araştırma verilerinin analizinde değişkenlere bağlı olarak SPSS paket programı kullanılarak Kruskal Wallis Testi, Mann Whitney U, Spearman Korelasyon Analizi gerçekleştirilmiştir.

\section{Bulgular}

Tablo 5. Üniversite Öğrencilerinin Cinsiyete Göre Ruminatif Düşünme Biçimleri, Sosyal İyi Olma Düzeyleri ve Duygusal Zekâ (İyi oluş, Öz kontrol, Duygusallık ve Sosyallik) Düzeylerine İlişkin Mann Whitney U Testi Sonuçları

\begin{tabular}{|c|c|c|c|c|c|}
\hline & Cinsiyet & $\mathrm{N}$ & Sira Ortalaması & $\mathrm{U}$ & $\mathrm{p}$ \\
\hline \multirow[t]{2}{*}{ Ruminatif Düşünme Biçimi } & Kadın & 426 & 352,64 & \multirow[t]{2}{*}{44670,00} & \multirow[t]{2}{*}{0,02} \\
\hline & Erkek & 244 & 305,57 & & \\
\hline \multirow[b]{2}{*}{ Sosyal İyi Olma } & Kadın & 425 & 339,05 & \multirow[t]{2}{*}{50128,00} & \multirow[t]{2}{*}{0,47} \\
\hline & Erkek & 244 & 327,94 & & \\
\hline \multirow[b]{2}{*}{ İyi Oluş } & Kadın & 426 & 344,71 & \multirow[t]{2}{*}{48048,00} & \multirow[t]{2}{*}{0,10} \\
\hline & Erkek & 244 & 319,42 & & \\
\hline \multirow[b]{2}{*}{ Öz Kontrol } & Kadın & 424 & 333,47 & \multirow[t]{2}{*}{51289,50} & \multirow[t]{2}{*}{0,85} \\
\hline & Erkek & 244 & 336,30 & & \\
\hline \multirow[b]{2}{*}{ Duygusallık } & Kadın & 426 & 337,91 & \multirow[t]{2}{*}{50946,50} & \multirow[t]{2}{*}{0,67} \\
\hline & Erkek & 244 & 331,30 & & \\
\hline \multirow[b]{2}{*}{ Sosyallik } & Kadın & 426 & 331,81 & 50410,50 & \multirow[t]{2}{*}{0,57} \\
\hline & Erkek & 243 & 344,59 & & \\
\hline \multirow[t]{2}{*}{ Toplam Duygusal Zekâ } & Kadın & 425 & 334,78 & \multirow[t]{2}{*}{51094,50} & \multirow[t]{2}{*}{0,89} \\
\hline & Erkek & 242 & 339,18 & & \\
\hline
\end{tabular}

${ }^{*} p<0,05$

Çalışma grubundaki üniversite öğrencilerinin cinsiyetlerine göre ruminatif düşünme biçimleri, sosyal iyi olma düzeyleri ve duygusal zekâ (iyi oluş, öz kontrol, duygusallık ve sosyallik) düzeylerine ilişkin değerler Mann Whitney $U$ testi ile hesaplanmış ve Tablo 5'te 
gösterilmiştir. Test sonuçlarına göre, erkek ve kadın öğrencilerin ruminatif düşünme biçimi puanları arasındaki fark anlamlı bulunmuştur. $(0,02, p<0,05)$. Bu bulguya göre, kadın öğrencilerin ruminatif düşünme biçimi puan ortalamaları erkek öğrencilerin puan ortalamasından fazladır (Sıra ortalaması 352,64>305,57). Sosyal iyi olma $(0.47, \mathrm{p}>0,05)$, duygusal zekâ $(0,89, \mathrm{p}>0,05)$ ve duygusal zekânın alt boyutları olan iyi oluş $(0,103, p>0,05)$ öz kontrol $(0,85, p>0,05)$, duygusallık $(0,67, p>0,05)$ ve sosyallik $(0,53, p>0,05)$ alt boyutlarında cinsiyete göre herhangi bir farklılaşma olmamıştır.

Tablo 6. Üniversite Öğrencilerinin Algıladıklar Gelir Düzeyine Göre Ruminatif Düşünme Biçimi, Sosyal İyi Olma Düzeyi ve Duygusal Zekâ (İyi oluş, Öz kontrol, Duygusallık ve Sosyallik) Puanlarna İlişkin Kruskal Wallis Testi Sonuçları

\begin{tabular}{|c|c|c|c|c|c|c|}
\hline & Algılanan Gelir Düzeyi & $\mathrm{N}$ & Sira Ortalamas1 & $\mathrm{sd}$ & $\mathrm{X}^{2}$ & $\mathrm{p}$ \\
\hline \multirow{3}{*}{$\begin{array}{l}\text { Ruminatif } \\
\text { Düşünme Biçimi }\end{array}$} & Düşük & 88 & 343,18 & \multirow{3}{*}{2} & \multirow{3}{*}{6,76} & \multirow{3}{*}{$0,03^{*}$} \\
\hline & Orta & 552 & 339,15 & & & \\
\hline & Yüksek & 30 & 245,88 & & & \\
\hline \multirow[b]{3}{*}{ Sosyal İyi Olma } & Düşük & 88 & 334,32 & \multirow{3}{*}{2} & \multirow{3}{*}{1,05} & \multirow{3}{*}{0,59} \\
\hline & Orta & 552 & 333,19 & & & \\
\hline & Yüksek & 30 & 370,27 & & & \\
\hline \multirow[b]{3}{*}{ İyi Oluş } & Düşük & 88 & 315,40 & \multirow{3}{*}{2} & \multirow{3}{*}{8,18} & \multirow{3}{*}{$0,01^{*}$} \\
\hline & Orta & 552 & 333,57 & & & \\
\hline & Yüksek & 30 & 429,92 & & & \\
\hline \multirow[b]{3}{*}{ Öz Kontrol } & Düşük & 88 & 346,85 & \multirow{3}{*}{2} & \multirow{3}{*}{2,46} & \multirow{3}{*}{0,29} \\
\hline & Orta & 550 & 335,30 & & & \\
\hline & Yüksek & 30 & 283,65 & & & \\
\hline \multirow[b]{3}{*}{ Duygusallık } & Düşük & 88 & 346,05 & \multirow{3}{*}{2} & \multirow{3}{*}{2,15} & \multirow{3}{*}{0,34} \\
\hline & Orta & 552 & 336,44 & & & \\
\hline & Yüksek & 30 & 287,22 & & & \\
\hline \multirow[b]{3}{*}{ Sosyallik } & Düşük & 88 & 342,13 & \multirow{3}{*}{2} & \multirow{3}{*}{1,24} & \multirow{3}{*}{0,53} \\
\hline & Orta & 551 & 331,96 & & & \\
\hline & Yüksek & 30 & 369,95 & & & \\
\hline \multirow{3}{*}{$\begin{array}{l}\text { Toplam } \\
\text { Duygusal Zekâ }\end{array}$} & Düşük & 88 & 330,10 & \multirow{3}{*}{2} & \multirow{3}{*}{0,18} & \multirow{3}{*}{0,91} \\
\hline & Orta & 549 & 335,30 & & & \\
\hline & Yüksek & 30 & 321,72 & & & \\
\hline
\end{tabular}

${ }^{*} p<0,05$

Üniversite öğrencilerinin algıladıkları gelir düzeylerine göre ruminatif düşünme biçimi, sosyal iyi olma düzeyi ve duygusal zekâ düzeyi (iyi oluş, öz kontrol, duygusallık ve sosyallik) puanlarına ilişkin Kruskal 
Wallis Testi Sonuçları Tablo 6'da gösterilmektedir. Bulgulara göre üniversite öğrencilerinin sosyal iyi olma $(0,59, p>0,05)$, öz kontrol $(0,29$, $\mathrm{p}>0,05)$, duygusallik $(0,34, \mathrm{p}>0,05)$, sosyallik $(0,53, \mathrm{p}>0,05)$ ve toplam duygusal zekâ puanlarının $(0,91, p>0,05)$ algıladıkları akademik başarıya göre anlamlı bir farklılık göstermediği görülmektedir.

Üniversite öğrencilerinin ruminatif düşünme biçimi puanlarının $(0,03$, $\mathrm{p}<0,05)$ ve duygusal zekânın alt boyutu olan iyi oluş puanlarının $(0,01$, $\mathrm{p}<0,05)$ algilanan gelir düzeyine göre anlamlı bir farklılaşma gösterdiği bulunmuştur. Farklılık gösteren gelir düzeylerini belirlemek amacıyla algılanan gelir düzeyine ikili olarak Mann Whitney U uygulanmıştır.

Tablo 7. Üniversite Öğrencilerinin Algıladıklan Gelir Düzeylerine Göre Ruminatif Düşünme Biçimleri ve İyi Oluş Puanlarna İlişkin Mann Whitney U Testi Sonuçlan

\begin{tabular}{|c|c|c|c|c|c|c|}
\hline & $\begin{array}{l}\text { Algilanan } \\
\text { Gelir Düzeyi }\end{array}$ & $\mathrm{N}$ & Sira Ortalaması & Sira Toplamı & $\mathrm{U}$ & $\mathrm{p}$ \\
\hline \multirow{6}{*}{$\begin{array}{l}\text { Ruminatif } \\
\text { Düşünme } \\
\text { Biçimi }\end{array}$} & Düşük & 88 & 323,71 & 28486,50 & \multirow[t]{2}{*}{24005,50} & \multirow[t]{2}{*}{0,86} \\
\hline & Orta & 552 & 319,99 & 176633,50 & & \\
\hline & Düşük & 88 & 63,97 & 5629,00 & \multirow[t]{2}{*}{927,00} & \multirow[t]{2}{*}{$0,01^{*}$} \\
\hline & Yüksek & 30 & 46,40 & 1392,00 & & \\
\hline & Orta & 552 & 295,66 & 163203,50 & \multirow[t]{2}{*}{5984,50} & \multirow[t]{2}{*}{$0,01^{*}$} \\
\hline & Yüksek & 30 & 214,98 & 6449,50 & & \\
\hline \multirow{6}{*}{ İyi oluş } & Düşük & 88 & 305,20 & 26857,50 & \multirow[t]{2}{*}{22941,500} & \multirow[t]{2}{*}{0,40} \\
\hline & Orta & 552 & 322,94 & 178262,50 & & \\
\hline & Düşük & 88 & 54,70 & 4813,50 & \multirow[t]{2}{*}{897,00} & \multirow[t]{2}{*}{0,09} \\
\hline & Yüksek & 30 & 73,58 & 2207,50 & & \\
\hline & Orta & 552 & 287,13 & 158498,00 & 22941,50 & \multirow[t]{2}{*}{$0,00^{*}$} \\
\hline & Yüksek & 30 & 371,83 & 11155,00 & & \\
\hline
\end{tabular}

${ }^{*} p<.05$

Tablo 7'de de görüleceği üzere algılanan gelir düzeyi düşük ve orta olanlar arasında ruminatif düşünme biçimi puanlarında anlamlı bir farklılık görülmemiştir $(0,86, p>0,05)$. Algılanan gelir düzeyi düşük olanların ruminatif düşünme biçimi puanları algılanan gelir düzeyi yüksek olanlara göre daha fazladır $(0,01, \mathrm{p}<0,05$; Sıra ortalaması $63,97>46,40)$. Ayrıca algılanan gelir düzeyi orta olanların ruminatif düşünme biçimi puanlarının algıladığı gelir düzeyi yüksek olanlara göre daha fazla olduğu görülmektedir $(0,01, \mathrm{p}<0,05$; sıra ortalaması 295,66>214,98). 
Yine Tablo 7'de algılanan gelir düzeyi düşük ve orta olanların iyi oluş puanlarında herhangi bir farklılaşma olmazken $(0,40, p>0,05)$, algılanan gelir düzeyi düşük ve yüksek olanların iyi oluş puanlarında da farklılaşma olmamıştır $(0,09, \mathrm{p}>0,05)$. Algılanan gelir düzeyi düzeyi yüksek olanların algılanan gelir düzeyi orta olanlara göre iyi oluş puan ortalamalarının daha fazla olduğu görülmektedir $(0,00, \mathrm{p}<0,05$; sıra ortalamas1 $287,13>371,83$ ).

Tablo 8. Algılanan Anne Baba Tutumuna Göre Ruminatif Düşünme Biçimleri, Sosyal İyi Olma ve Duygusal Zekâ (İyi oluş, Öz kontrol, Duygusallık ve Sosyallik) Puanlarına ilişkin Kruskal Wallis Testi Sonuçları

\begin{tabular}{|c|c|c|c|c|c|c|}
\hline & $\begin{array}{l}\text { Algilanan Anne Baba } \\
\text { Tutumu }\end{array}$ & $\mathrm{N}$ & Sira Ortalaması & $\mathrm{sd}$ & $X^{2}$ & $\mathrm{p}$ \\
\hline \multirow{4}{*}{$\begin{array}{l}\text { Ruminatif } \\
\text { Düşünme Biçimi }\end{array}$} & İlgisiz & 12 & 365,71 & & \multirow{4}{*}{22,16} & \multirow{4}{*}{$0,00^{*}$} \\
\hline & Otoriter & 76 & 387,07 & & & \\
\hline & Koruyucu & 428 & 347,17 & 3 & & \\
\hline & Demokratik & 154 & 275,25 & & & \\
\hline \multirow{4}{*}{ Sosyal İyi Olma } & İlgisiz & 12 & 292,71 & \multirow{4}{*}{3} & \multirow{4}{*}{11,20} & \multirow{4}{*}{$0,01^{*}$} \\
\hline & Otoriter & 76 & 372,77 & & & \\
\hline & Koruyucu & 428 & 344,16 & & & \\
\hline & Demokratik & 154 & 294,44 & & & \\
\hline \multirow{4}{*}{ İyi oluş } & İlgisiz & 12 & 280,25 & \multirow{4}{*}{3} & \multirow{4}{*}{6,46} & \multirow{4}{*}{0,09} \\
\hline & Otoriter & 76 & 305,72 & & & \\
\hline & Koruyucu & 428 & 331,84 & & & \\
\hline & Demokratik & 154 & 364,68 & & & \\
\hline \multirow{4}{*}{ Öz kontrol } & İlgisiz & 12 & 290,67 & \multirow{4}{*}{3} & \multirow{4}{*}{11,11} & \multirow{4}{*}{$0,01^{*}$} \\
\hline & Otoriter & 75 & 359,37 & & & \\
\hline & Koruyucu & 427 & 346,70 & & & \\
\hline & Demokratik & 154 & 291,96 & & & \\
\hline \multirow{4}{*}{ Duygusallık } & İlgisiz & 12 & 325,75 & \multirow{4}{*}{3} & \multirow{4}{*}{16,58} & \multirow{4}{*}{$0,00^{*}$} \\
\hline & Otoriter & 76 & 381,18 & & & \\
\hline & Koruyucu & 428 & 346,22 & & & \\
\hline & Demokratik & 154 & 283,91 & & & \\
\hline \multirow{4}{*}{ Sosyallik } & İlgisiz & 12 & 291,75 & \multirow{4}{*}{3} & \multirow{4}{*}{6,03} & \multirow{4}{*}{0,11} \\
\hline & Otoriter & 75 & 343,33 & & & \\
\hline & Koruyucu & 428 & 345,82 & & & \\
\hline & Demokratik & 154 & 304,23 & & & \\
\hline \multirow{4}{*}{$\begin{array}{l}\text { Toplam } \\
\text { Duygusal Zekâ }\end{array}$} & İlgisiz & 12 & 295,38 & \multirow{4}{*}{3} & \multirow{4}{*}{3,92} & \multirow{4}{*}{0,27} \\
\hline & Otoriter & 76 & 335,17 & & & \\
\hline & Koruyucu & 428 & 343,55 & & & \\
\hline & Demokratik & 154 & 310,01 & & & \\
\hline
\end{tabular}

${ }^{*} p<0,05$ 
Üniversite öğrencilerinin algılanan anne baba tutumuna göre ruminatif düşünme biçimi, sosyal iyi olma ve duygusal zekâ (iyi oluş, öz kontrol, duygusallık ve sosyallik) puanlarına ilişkin yapılan Kruskal Wallis Testi sonuçları Tablo 8'de gösterilmektedir. Yapılan bu analizlerde toplam duygusal zekâ $(0,27, \mathrm{p}>0,05)$ ve duygusal zekânın alt boyutları olan sosyallik $(0,11, \mathrm{p}>0,05)$ ve iyi oluş $(0,09, \mathrm{p}>0,05)$ puanlarının algılanan anne baba tutumuna göre farklılık göstermediği görülmektedir. Ruminatif düşünme biçimi $(0,00, p<0,05)$, sosyal iyi olma $(0,01, \mathrm{p}<0,05)$ ve duygusal zekânın alt boyutları olan öz kontrol $(0,01, \mathrm{p}<$ $0,05)$ ve duygusallık $(0,00, p<0,05)$ alt boyutlarında ise anne-baba tutumu değişkenine göre anlamlı düzeyde farklılık bulunmuştur. Farklılık gösteren anne baba tutumlarını belirlemek amacıyla algılanan anne baba tutumlarına ikili olarak Mann Whitney U uygulanmıştır.

Tablo 9. Üniversite Öğrencilerinin Algıladıkları Anne Baba Tutumlarına Göre Ruminatif Düşünme Biçimi Puanlarına İlişkin Mann Whitney U Testi Sonuçlarn

\begin{tabular}{|c|c|c|c|c|c|c|}
\hline & $\begin{array}{l}\text { Algilanan anne } \\
\text { baba tutumu }\end{array}$ & $\mathrm{N}$ & Sira Ortalaması & Sira Toplamı & $\mathrm{U}$ & $\mathrm{p}$ \\
\hline \multirow{12}{*}{$\begin{array}{l}\text { Ruminatif } \\
\text { Düşünme } \\
\text { Biçimi }\end{array}$} & İlgisiz & 12 & 42,38 & 508,50 & \multirow[t]{2}{*}{430,50} & \multirow[t]{2}{*}{0,75} \\
\hline & Otoriter & 76 & 44,84 & 3407,50 & & \\
\hline & İlgisiz & 12 & 232,08 & 2785,00 & \multirow[t]{2}{*}{2429,00} & \multirow[t]{2}{*}{0,74} \\
\hline & Koruyucu & 428 & 220,18 & 94235,00 & & \\
\hline & İlgisiz & 12 & 104,25 & 1251,00 & \multirow[t]{2}{*}{675,00} & \multirow[t]{2}{*}{0,12} \\
\hline & Demokratik & 154 & 81,88 & 12610,00 & & \\
\hline & Otoriter & 76 & 279,19 & 21218,50 & \multirow[t]{2}{*}{14235,50} & \multirow[t]{2}{*}{$0,08^{*}$} \\
\hline & Koruyucu & 428 & 247,76 & 106041,50 & & \\
\hline & Otoriter & 76 & 140,04 & 10643,00 & \multirow[t]{2}{*}{3987,00} & \multirow[t]{2}{*}{$0,00^{*}$} \\
\hline & Demokratik & 154 & 103,39 & 15922,00 & & \\
\hline & Koruyucu & 428 & 308,24 & 131926,00 & \multirow[t]{2}{*}{25792,00} & \multirow[t]{2}{*}{$0,00^{*}$} \\
\hline & Demokratik & 154 & 244,98 & 37727,00 & & \\
\hline
\end{tabular}

${ }^{*} p<.05$

Tablo 9'da görüleceği üzere algilanan anne baba tutumu ilgisiz ve otoriter arasinda $(0,75, \mathrm{p}>0,05)$, ilgisiz ve koruyucu arasinda $(0,74$, $\mathrm{p}>0,05)$, ilgisiz ve demokratik arasinda $(0,12, p>0,05)$ herhangi bir farklılaşma yoktur. Ortalama puanlara bakıldığında algılanan anne baba tutumu otoriter olanların ruminatif düşünme biçimi puanları koruyucu tutumu algılayanlara göre anlamlı olarak daha fazla olduğu 
görülmektedir $(0,08, \mathrm{p}<0,05$; sira ortalaması 279,19> 247,76). Algılanan anne baba tutumu otoriter olanların ruminatif düşünme biçimi puanları algilanan anne baba tutumu demokratik olanlara göre daha fazladır $(0,00, p<0,05$; sira ortalamasi 140,04>103,39). Algilanan anne baba tutumu koruyucu olanların ruminatif düşünme biçimi puanları algılanan anne baba tutumu demokratik olanlara göre daha yüksektir $(0,00, p<0,05$; sıra ortalaması $308,24>244,98)$.

Tablo 10. Üniversite Öğrencilerinin Algıladıkları Anne Baba Tutumuna Göre Sosyal İyi Olma Puanlarına İlişkin Mann Whitney U Testi Sonuçları

\begin{tabular}{|c|c|c|c|c|c|c|}
\hline & $\begin{array}{l}\text { Algilanan Anne } \\
\text { Baba Tutumu }\end{array}$ & $\mathrm{N}$ & Sira Ortalaması & Sira Toplamı & $\mathrm{U}$ & $\mathrm{p}$ \\
\hline \multirow{12}{*}{$\begin{array}{l}\text { Sosyal İyi } \\
\text { Olma }\end{array}$} & İlgisiz & 12 & 34,33 & 412,00 & \multirow[t]{2}{*}{334,00} & \multirow[t]{2}{*}{0,15} \\
\hline & Otoriter & 75 & 45,55 & 3416,00 & & \\
\hline & İlgisiz & 12 & 186,92 & 2243,00 & \multirow[t]{2}{*}{2165,00} & \multirow[t]{2}{*}{0,35} \\
\hline & Koruyucu & 428 & 221,44 & 94777,00 & & \\
\hline & İlgisiz & 12 & 12 & 84,46 & \multirow[t]{2}{*}{912,50} & \multirow[t]{2}{*}{0,94} \\
\hline & Demokratik & 154 & 154 & 83,43 & & \\
\hline & Otoriter & 75 & 270,70 & 20302,50 & \multirow[t]{2}{*}{14647,50} & \multirow[t]{2}{*}{0,22} \\
\hline & Koruyucu & 428 & 248,72 & 106453,50 & & \\
\hline & Otoriter & 75 & 132,52 & 9939,00 & \multirow[t]{2}{*}{4461,00} & \multirow[t]{2}{*}{$0,00^{*}$} \\
\hline & Demokratik & 154 & 106,47 & 16396,00 & & \\
\hline & Koruyucu & 428 & 303,00 & 129683,50 & \multirow[t]{2}{*}{28034,50} & \multirow[t]{2}{*}{$0,00^{*}$} \\
\hline & Demokratik & 154 & 259,54 & 39969,50 & & \\
\hline
\end{tabular}

${ }^{*} p<.05$

Tablo 10'da uygulanan Mann Whitney U testi sonuçlarına bakıldığında algilanan anne baba tutumu ilgisiz olan ile otoriter olan arasinda $(0,15, p>0,05)$, ilgisiz ve koruyucu olan arasinda $(0,35, \mathrm{p}>0,05)$, ilgisiz ve demokratik olan arasinda $(0,94, \mathrm{p}>0,05)$ ve otoriter ve koruyucu arasinda $(0,22, p>0,05)$ sosyal iyi olma puanlarında anlamlı bir farklılaşma olmamıştır. Algılanan anne baba tutumu otoriter olan üniversite öğrencilerinin sosyal iyi olma puan ortalamaları anne baba tutumu demokratik olanlara göre daha yüksektir $(0,00, p<0,05$; sira ortalaması 132,52>106,47). Ayrica algilanan anne baba tutumu koruyucu olanların sosyal iyi olma puan ortalamaları algılanan anne baba tutumu demokratik olanlara göre daha yüksektir $(0,00, p<0,05$; sira ortalaması 303,00>259,54). 
Tablo 11'de uygulanan Mann Whitney U testi sonuçlarına bakıldığında üniversite öğrencilerinin duygusal zekânın alt boyutu olan duygusallık alt boyut puanı algıladıkları anne baba tutumlarına göre ilgisiz ve otoriter olanlar arasinda $(0,36, p>0,05)$, ilgisiz ve koruyucu olanlar arasında $(0,72, \mathrm{p}>0,05)$, ilgisiz ve demokratik olanlar arasinda $(0,48$, $p>0,05)$ ve otoriter ve koruyucu olanlar arasinda $(0,12, p>0,05)$ anlamlı bir farklılık göstermemektedir. Algılanan anne baba tutumu otoriter olanların demokratik olanlara göre duygusallık alt boyut puanlarının daha fazla olduğu görülmektedir $(0,00, p<0,05$; sıra ortalaması 136,86>104,96). Ayrica algılanan anne baba tutumu koruyucu olanların duygusallık alt boyut puanları algilanan anne baba tutumu demokratik olanlara göre daha fazladır $(0,00, \mathrm{p}<0,05$; sira ortalaması 306,01>251,17).

Tablo 11. Üniversite Öğrencilerinin Algıladıkları Anne Baba Tutumlarına Göre Duygusallık Alt Boyutu Puanlarına İlişkin Mann Whitney U Testi Sonuçlarn

\begin{tabular}{|c|c|c|c|c|c|c|}
\hline & $\begin{array}{l}\text { Algilanan Anne } \\
\text { Baba Tutumu }\end{array}$ & $\mathrm{N}$ & Sira Ortalamas & Sira Toplamı & $\mathrm{U}$ & $\mathrm{p}$ \\
\hline \multirow{12}{*}{$\begin{array}{l}\text { Duygusallık } \\
\text { Alt Boyutu }\end{array}$} & İlgisiz & 12 & 38,29 & 459,50 & \multirow[t]{2}{*}{381,50} & \multirow[t]{2}{*}{0,36} \\
\hline & Otoriter & 76 & 45,48 & 3456,50 & & \\
\hline & İlgisiz & 12 & 207,71 & 2492,50 & \multirow[t]{2}{*}{2414,50} & \multirow[t]{2}{*}{0,72} \\
\hline & Koruyucu & 428 & 220,86 & 94527,50 & & \\
\hline & İlgisiz & 12 & 92,75 & 1113,00 & \multirow[t]{2}{*}{813,00} & \multirow[t]{2}{*}{0,48} \\
\hline & Demokratik & 154 & 82,78 & 12748,00 & & \\
\hline & Otoriter & 76 & 136,86 & 10401,00 & \multirow[t]{2}{*}{14489,00} & \multirow[t]{2}{*}{0,12} \\
\hline & Koruyucu & 154 & 104,96 & 16164,00 & & \\
\hline & Otoriter & 76 & 136,86 & 10401,00 & \multirow[t]{2}{*}{4229,00} & \multirow[t]{2}{*}{$0,00^{*}$} \\
\hline & Demokratik & 154 & 104,96 & 16164,00 & & \\
\hline & Koruyucu & 428 & 306,01 & 130972,50 & \multirow[t]{2}{*}{26745,50} & \multirow[t]{2}{*}{$0,00^{*}$} \\
\hline & Demokratik & 154 & 251,17 & 38680,50 & & \\
\hline
\end{tabular}

${ }^{*} p<.05$

Tablo 11'de uygulanan Mann Whitney U testi sonuçlarına bakıldığında üniversite öğrencilerinin duygusal zekânın alt boyutu olan duygusallık alt boyut puanı algıladıkları anne baba tutumlarına göre ilgisiz ve otoriter olanlar arasinda $(0,36, \mathrm{p}>0,05)$, ilgisiz ve koruyucu olanlar arasinda $(0,72, \mathrm{p}>0,05)$, ilgisiz ve demokratik olanlar arasinda $(0,48, \mathrm{p}>0,05)$ ve otoriter ve koruyucu olanlar arasinda $(0,12, p>0,05)$ anlamlı bir farklılık göstermemektedir. Algılanan anne baba tutumu otoriter olanların demokratik olanlara göre duygusallık alt boyut puanlarının daha fazla olduğu görülmektedir $(0,00, p<0,05$; sıra 
ortalaması 136,86>104,96). Ayrica algilanan anne baba tutumu koruyucu olanların duygusallik alt boyut puanları algilanan anne baba tutumu demokratik olanlara göre daha fazladır $(0,00, p<0,05$; sıra ortalaması 306,01>251,17).

Tablo 12. Üniversite Öğrencilerinin Algıladıkları Anne Baba Tutumuna Göre Öz Kontrol Alt Boyutu Puanlarına İlişkin Mann Whitney U Testi Sonuçları

\begin{tabular}{|c|c|c|c|c|c|c|}
\hline & $\begin{array}{l}\text { Algilanan Anne } \\
\text { Baba Tutumu }\end{array}$ & $\mathrm{N}$ & Sira Ortalaması & Sira Toplamı & $\mathrm{U}$ & $\mathrm{p}$ \\
\hline \multirow{12}{*}{$\begin{array}{l}\text { Öz } \\
\text { Kontrol } \\
\text { Alt } \\
\text { Boyutu }\end{array}$} & İlgisiz & 12 & 36,54 & 438,50 & 360,50 & 0,26 \\
\hline & Otoriter & 75 & 45,19 & 3389,50 & & \\
\hline & İlgisiz & 12 & 182,33 & 2188,00 & 2110,00 & 0,29 \\
\hline & Koruyucu & 427 & 221,06 & 94392,00 & & \\
\hline & İlgisiz & 12 & 84,79 & 1017,50 & 908,00 & 0,92 \\
\hline & Demokratik & 154 & 83,40 & 12843,50 & & \\
\hline & Otoriter & 75 & 260,41 & 19530,50 & 15344,50 & 0,56 \\
\hline & Koruyucu & 427 & 249,94 & 106722,50 & & \\
\hline & Otoriter & 75 & 129,77 & 9733,00 & 4667,00 & $0,01^{*}$ \\
\hline & Demokratik & 154 & 107,81 & 16602,00 & & \\
\hline & Koruyucu & 427 & 303,71 & 129684,50 & 27451,00 & $0,00^{*}$ \\
\hline & Demokratik & 154 & 255,76 & 39386,50 & & \\
\hline
\end{tabular}

${ }^{*} p<.05$

Tablo 12'de uygulanan Mann Whitney U testi sonuçlarına bakıldığında üniversite öğrencilerinin duygusal zekânın alt boyutu olan öz kontrol alt boyut puanları algıladıkları anne baba tutumlarına göre ilgisiz ve otoriter olanlar arasinda $(0,26, p>0,05)$, ilgisiz ve koruyucu olanlar arasinda $(0,29, p>0,05)$, ilgisiz ve demokratik olanlar arasinda $(0,92, p>0,05)$ ve otoriter ve koruyucu olanlar arasinda $(0,56, p>0,05)$ anlamlı bir farklılık göstermemektedir. Algılanan anne baba tutumu otoriter olanların demokratik olanlara göre öz kontrol alt boyut puanlarının daha fazla olduğu görülmektedir $(0,01, \mathrm{p}<0,05$; sira ortalamas1 129,77>107,81). Ayrica algılanan anne baba tutumu koruyucu olanların öz kontrol alt boyut puanları algılanan anne baba tutumu demokratik olanlara göre daha fazladir $(0,00, \mathrm{p}<0,05$; sira ortalaması 303,71>255,76). 
Tablo 13 : Üniversite Öğrencilerinin Algıladıklan Akademik Başarıya Göre Ruminatif Düşünme Biçimleri, Sosyal İyi Olma ve Duygusal Zekâ (İyi oluş, Öz kontrol, Duygusallık ve Sosyallik) Puanlarna İlişkin Kruskal Wallis Testi Sonuçlarn

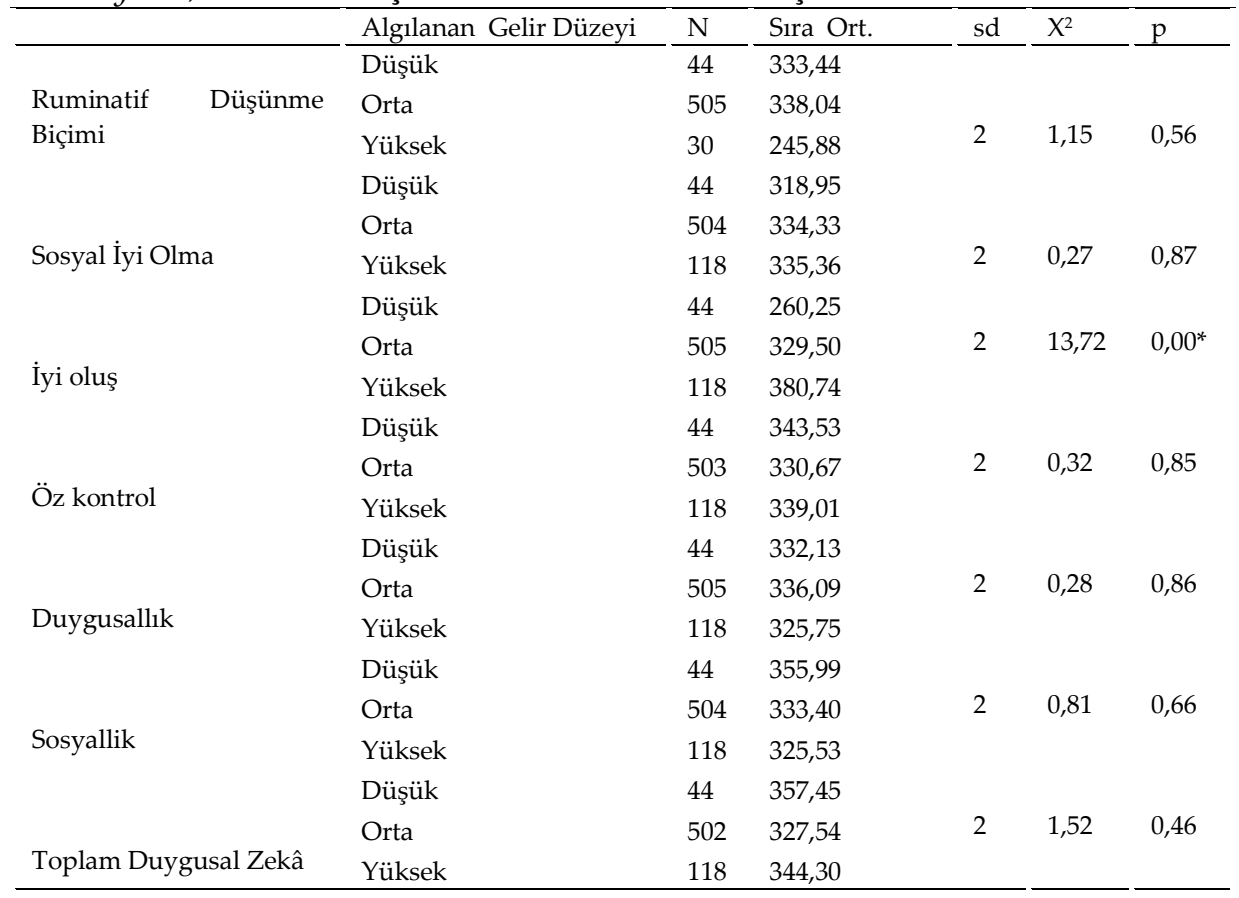

${ }^{*} p<0,05$

Tablo 13'te üniversite öğrencilerinin algıladıkları akademik başarıya göre ruminatif düşünme biçimi, sosyal iyi olma ve duygusal zekâ (iyi oluş, öz kontrol, duygusallık ve sosyallik) puanlarına ilişkin Kruskal Wallis Testi uygulanmıştır. Yapılan analizin sonuçları incelendiğinde ise ruminatif düşünme biçimi $(0,56, p>0,05)$, sosyal iyi olma $(0,87, p>0,05)$, toplam duygusal zekâ $(0,46, p>0,05)$ ve duygusal zekânın alt boyutları olan öz kontrol $(0,85, p>0,05)$, duygusallik $(0,86, p>0,05)$ ve sosyallik $(0,66, p>0,05)$ alt boyutlarında algılanan akademik başarı değişkenine göre anlamlı bir farklılaşma olmadı̆̆ı görülmektedir. Duygusal zekânın alt boyutu olan iyi oluş ile algılanan akademik başarı arasında anlamlı bir farklılık vardır $(0,00$, p<0,05). Farklılık gösteren anne baba tutumlarını belirlemek amacıyla algılanan anne baba tutumlarına ikili olarak Mann Whitney U uygulanmıştır. 
Tablo 14: Üniversite Öğrencilerinin Algıladıklarn Akademik Başan Düzeylerine Göre İyi Oluş Alt Boyutu Puanlarna İlişkin Mann Whitney U Testi Sonuçlan

\begin{tabular}{|c|c|c|c|c|c|c|}
\hline & $\begin{array}{l}\text { Algılanan Akademik } \\
\text { Başarı Düzeyi }\end{array}$ & $\mathrm{N}$ & $\begin{array}{l}\text { Sira } \\
\text { Ortalamas1 }\end{array}$ & Sira Toplamı & $\mathrm{U}$ & $\mathrm{p}$ \\
\hline \multirow{6}{*}{$\begin{array}{l}\text { İyi } \\
\text { Oluş }\end{array}$} & Düşük & 44 & 220,52 & 9703,00 & \multirow[t]{2}{*}{8713,00} & \multirow[t]{2}{*}{, $01^{*}$} \\
\hline & Orta & 505 & 279,75 & 141272,00 & & \\
\hline & Düşük & 44 & 62,23 & 2738,00 & \multirow[t]{2}{*}{1748,00} & \multirow[t]{2}{*}{, $00^{*}$} \\
\hline & Yüksek & 118 & 88,69 & 10465,00 & & \\
\hline & Orta & 505 & 302,76 & 152892,50 & \multirow[t]{2}{*}{25127,00} & \multirow[t]{2}{*}{, $00^{*}$} \\
\hline & Yüksek & 118 & 351,56 & 41483,50 & & \\
\hline
\end{tabular}

${ }^{*} p<.05$

Tablo 14'te bulunan Mann Whitney U testi sonuçlarına göre üniversite öğrencilerinin algıladıkları akademik başarı düzeyi orta olanların iyi oluş alt boyut puan ortalamaları algılanan akademik başarısı düşük olanlara göre daha fazladir $(0,01, p<0,05$; sira ortalamas $279,75>220,52)$. Alg1lanan akademik başarı düzeyi yüksek olanların iyi oluş alt boyut puan ortalamaları algılanan akademik başarısı düşük olanlara göre daha fazladır $(0,00, p<0,05$; sira ortalaması 88,69>62,23). Son olarak algılanan akademik başarısı yüksek olanların iyi oluş alt boyut puan ortalamaları algılanan akademik başarısı orta olanlara göre daha fazladır $(0,00, \mathrm{p}<0,05$; sıra ortalaması 351,56>302,76).

Tablo 15. Üniversite Öğrencilerinin Ruminatif Düşünme Biçimleri ve Sosyal İyi Olma Düzeyleri ile Duygusal Zekâ Düzeyleri ile Arasındaki Spearman Stra Farklarn Korelasyon Katsayısı

\begin{tabular}{|c|c|c|c|}
\hline & & Ruminatif Düşünme Biçimi & Sosyal İyi Olma \\
\hline \multirow[b]{3}{*}{ İyi Oluş } & Korelasyon Katsayısı & 0,20 & 0,01 \\
\hline & $\mathrm{p}$ & 0,59 & 0,73 \\
\hline & $\mathrm{N}$ & 670 & 670 \\
\hline \multirow[b]{3}{*}{ Öz Kontrol } & Korelasyon Katsayısı & $-0,44^{* *}$ & $-0,15^{* *}$ \\
\hline & $\mathrm{p}$ & 0,00 & 0,00 \\
\hline & $\mathrm{N}$ & 670 & 670 \\
\hline \multirow[b]{3}{*}{ Duygusallık } & Korelasyon Katsayısı & $-0,14^{* *}$ & $-0,16^{* *}$ \\
\hline & $\mathrm{p}$ & 0,00 & 0,00 \\
\hline & $\mathrm{N}$ & 670 & 670 \\
\hline \multirow{4}{*}{ Sosyallik } & Korelasyon Katsayısı & $-0,12^{* *}$ & $-0,06$ \\
\hline & $\mathrm{p}$ & 0,00 & 0,08 \\
\hline & $\mathrm{N}$ & 670 & 670 \\
\hline & Korelasyon Katsayısı & $-0,26^{* *}$ & $-0,13^{* *}$ \\
\hline Toplam & $\mathrm{p}$ & 0,00 & 0,00 \\
\hline Duygusal Zekâ & $\mathrm{N}$ & 670 & 670 \\
\hline
\end{tabular}

$* * p<.001$ 
Yapılmış olan Spearman Korelasyon Analizi sonucunda elde edilen sonuç Tablo 15 'te gösterilmiştir. Üniversite öğrencilerinin ruminatif düşünme biçimleri ve sosyal iyi olma düzeyleri ile iyi oluş alt boyutun arasında anlamlı bir ilişki yoktur $(p=0,59, p=0,73, p>0,01)$. Üniversite öğrencilerinin sosyal iyi olma ve sosyallik alt boyutu arasında anlamlı bir ilişki bulunmazken $(p=0,08, p>0,01)$ ruminatif düşünme biçimi ve sosyallik alt boyutu arasında düşük düzeyde anlamlı bir ilişki vardır ( $\mathrm{r}=$ $-0,12, \mathrm{p}<0,01)$. Üniversite öğrencilerinin ruminatif düşünme biçimleri ve sosyal iyi olma düzeyleri ile öz kontrol alt boyutu ( $\mathrm{r}=-0,44, \mathrm{r}=-0,15$, $\mathrm{p}<0,01)$, duygusallik alt boyutu $(\mathrm{r}=-0,14, \mathrm{r}=-0,16, \mathrm{p}<0,01)$ ve toplam duygusal zekâ düzeyleri $(\mathrm{r}=-0,26, \mathrm{r}=-0,13, \mathrm{p}<0,01)$ arasında anlamlı bir ilişki olduğu görülmektedir. Bu ilişkilerin negatif yönde zayıf ilişkiler olduğu görülürken sadece ruminatif düşünme biçimi ve öz kontrol alt boyutu arasındaki ilişki orta düzeydedir.

\section{Tartışma}

Araştırmanın bulgularına göre kadın öğrencilerin ruminatif düşünme biçimi puanlarının erkek öğrencilerin ruminatif düşünme biçimi puanına göre daha yüksek olduğu bulunmuştur. Nolen Hoeksema ve Jackson da (2001), kadınların erkeklere oranla duygularını daha kontrol edilemez olarak algılayarak ilişkilerin duygusal sorumluluğunu daha fazla hissettikleri ve yaşamdaki önemli olaylarda daha az kontrol sağladıklarını ifade etmişlerdir.

Üniversite öğrencilerinin sosyal iyi olma düzeylerinde, toplam duygusal zekâ puanlarında ve duygusal zekânın tüm alt boyutlarında cinsiyetlerine göre anlamlı bir farklılık olmadığı görülmektedir.

Algılanan gelir düzeyi orta ve düşük olan üniversite öğrencilerinin algılanan gelir düzeyi yüksek olanlara göre ruminatif düşünme biçimi puanları anlamlı olarak daha fazladır. Talavera, Paulus, Garza, Ochoa-Perez, Lemaire, Valdivieso, Bogiaizian, Robles, Bakhshaie, Manning, Walker, Businelle, Zvolensky (2018) tarafindan yapılan araştırmada gelir düzeyi düşük olan bireylerin gelir düzeyi yüksek olanlara göre ruminatif düşünme puanının yüksek olduğu sonucu bulunmuştur. Bu bağlamda bireylerin geleceklerine ilişkin maddi kaygılarının ruminatif düşünmelerini arttıracağ1 düşünülebilir. 
Üniversite öğrencilerinin gelir düzeyine göre sosyal iyi olma düzeylerinde, toplam duygusal zekâ puanlarında ve öz kontrol, duygusallık, sosyallik boyutlarında anlamlı bir farklılık bulunmamıştır.

Öğrencilerde duygusal zekanın iyi oluş alt boyutunun algılanan gelir düzeyi yüksek olanların lehine olduğu görülmektedir. Diener ve Diener (1996), iyi oluşun en güçlü yordayıcılarından birinin gelir düzeyi olduğunu ifade etmişlerdir. Bu yüzden gelir düzeyi yükseldikçe iyi oluş düzeyinde de artış olması beklenir bir bulgudur.

Yapılan araştırmada üniversite öğrencilerinin algılanan anne baba tutumu otoriter ve koruyucu olanların ruminatif düşünme biçimi puanlarının algilanan anne baba tutumu demokratik olanlara göre yüksek olduğu sonucuna varılmıştır. Koruyucu anne baba tutumuna sahip olan aileler çocuğa gereğinden fazla kontrol ve özen gösterir bu da çocuğun diğer kimselere aşırı bağımlı olması ile kendi kendine yetmesine engel teşkil eder (Yavuzer, 1998, s.126). Kendi kendine yetemeyen çocuğun ileriki hayatında yaşayabileceği varsayılan yetersizlik hissi bireyde olumsuz otomatik düşünceler oluşturabilir. Otoriter anne baba tutumunda ise; anne babası tarafından her davranışı ve söylemi planlanmış olan çocuk kendini ifade edemez. Ayrıca otoriter tutumda sık uygulanan ceza, çocukta suçluluk duygusu yaratır, çocuğun özgüvenini düşürür ve bazı çocuklarda da asi ve kızgın davranışlara sebep olur (Çetinkaya, 2016, s.105). Otoriter tutumun sonucu olarak kendini ifade edemeyen ve suçluluk yaşayan çocuğun var olan kızgınlıkları üzerine tekrarlayıcı düşünceler yaşaması muhtemeldir. Demokratik tutuma sahip anne babalar çocuklarının fikirlerini önemseyip, iç denetim geliştirmesini önemsemektedirler (Dönmezer, 1999, s.60). Fikirleri önemsenen çocukların daha rahat bir şekilde kendilerini ifade edebilmeleri ile takıntılı düşüncelerinin daha az olacağ araştırma bulguları beklenir sonuçları beraberinde getirmiştir.

Araştırmada üniversite öğrencilerinin algıladıkları anne baba tutumu otoriter ve koruyucu olanların sosyal iyi olma puan ortalamalarının algılanan anne baba tutumu demokratik olanlara göre fazla olduğu görülmektedir. Anne ve babadan herhangi birisinin ya da her ikisinin baskısı altında olan çocuk nazik, dikkatli ve dürüst olabilmektedir (Yavuzer, 1998, s.127). Bireyin bu gibi yeterliklere sahip olması sosyal anlamda iyi oluşu için yardımcı unsur olabileceği düşünülmektedir. Ayrıca Köksal, Dilci ve Koç (2013) tarafından yapılan araştırmada sosyal anlamda problem yaşayan 
çocukların problem yaşama sebeplerinde aileleri kadar bireyin çevresinin de etkili olduğu ve aile hayatında sorun olmasa bile sosyal anlamda problem yaşayanların olduğu sonucu bulunmuştur. Bu bağlamda bireyin sosyal iyi oluşunda anne baba tutumlarının yanı sıra çevresel etkenler de göz önüne alındığında bulgular anlaşılır olarak yorumlanmaktadır.

Yapilan incelemede algilanan anne baba tutumu otoriter ve koruyucu olanların demokratik olanlara göre daha fazla öz kontrol ve duygusallık puanlarına sahip oldukları görülmüştür. Sosyallik, iyi oluş ve toplam duygusal zekâ puanında anne baba tutumuna göre herhangi bir farklılaşma olmadığı görülmüştür. Duygusal zekâ kavramının geliştirilebilir olması sebebiyle anne baba tutumlarının yanı sıra öğretim sürecinin de bireyin gelişiminde etkili olması; özellikle öz kontrol ve duygusallık alt boyutlarının duygusal zekâ puanlarının yüksek çıkmasında etkili olduğu düşünülebilir.

Algılanan akademik başarıya göre üniversite öğrencilerinin ruminatif düşünme biçimi puanlarında ve sosyal iyi olma puanlarında, duygusal zekanın öz kontrol, duygusallık, sosyallik ve toplam duygusal zeka puanında anlamlı bir farklılaşma olmadığı sonucuna ulaşılmıştır.

Duygusal zekanın iyi oluş alt boyut puanında algılanan akademik başarısı yüksek olanların düşük ve orta olanlara göre daha fazla olduğu bulunmuştur. Aynı zamanda algılanan akademik başarısı orta olanların düşük olanlara göre iyi oluş alt boyut puanlarının da fazla olduğu görülmektedir. Diener ve Diener (1996), iyi oluşun en güçlü yordayıcılarından biri gelir düzeyi iken bir diğerinin statü olduğunu ifade etmişlerdir. Üniversite öğrencilerinin akademik başarıları da ilerideki statülerinin göstergelerinden biri olarak nitelendirildiğinde iyi oluş puanında artış olması beklenir bir bulgudur.

Üniversite öğrencilerinin ruminatif düşünme biçimlerinin duygusal zekâ düzeyleri ile negatif yönde anlamlı bir ilişkisi olduğu bulunmuştur. Cenkseven Önder ve Utkan (2018) tarafından yapılan araştırmada öğrencilerin bilinçli farkındalıklarının artması onların ruminasyon düzeylerini azaltmakta ve bu düşüşle birlikte algıladıkları stresin de azaldığını göstermektedir. Duygusal zekânın stres toleransı geliştirmesi, bireyin farkındalıklarını artırması; ruminasyonun stresli bir yaşam sonucunda olumsuz çıkarımlarda bulunması ile zıt durumlar olduğu görülmektedir.

Üniversite öğrencilerinin ruminatif düşünme biçimleri ile sosyallik ve duygusallık alt boyut puanları arasında düşük düzeyde anlamlı bir ilişki 
bulunmuştur. Sosyallik alt boyutunda diğer insanlarla baş edebilme, duygusallik alt boyutunda hisleri ayırt edebilmek ön planda iken (Petrides ve Furnham, 2001); ruminatif düşünme biçimi sosyal etkileşimlerdeki durumları sürekli düşünmeyi (Baer, 2015, s.62) ele aldığ1 için bireyin sosyalliğine yönelik olumsuz etkiler yaratabilir. Ruminatif düşünme biçiminde birey, var olan hislerini kontrol edilemez olarak algıladığ için duyguların ayırt etmekte güçlük yaşayabileceği düşünülebilmektedir.

Ruminatif düşünme biçimi ve duygusal zekânın alt boyutu olan öz kontrol boyutu ile arasında negatif orta düzeyde anlamlı bir ilişki olduğu görülmektedir. Erguvan Eryılmaz ve Tosun'a (2013) göre kontrol kavramı bir bütün olarak kaygıyla yakından bir ilişki içindedir ve bir kişi herhangi bir nedenle kaygı hissetmeye başlarsa, bunu hemen kontrol duygusunun kaybı izlemektedir. Ruminatif düşünmeler içinde kaygıyı barındırması sebebiyle öz kontrol alt boyutu ile negatif yönde ilişkisinin olması beklenir bir sonuç olmuştur.

Üniversite öğrencilerinin sosyal iyi olma düzeylerinin duygusal zekâ düzeyleri ile ilişkisinin de negatif yönde anlamlı olduğu görülmektedir. Buluş'a (1997) göre bireyler yaşamın yoğun temposu içinde kaybolup gitmekte, güvenden yoksun ilişkiler üzerine hayatlarını kurmakta ve giderek birbirinden uzaklaşan ve yalnızlaşan bir toplum olarak hayatını sürdürmektedir. Günümüz toplumunda toplum bilincinin yerini bireyselliğin almış olması bireylerin kendini geliştirmeye daha fazla adaması, kendi mutluluğunu, bağımsızlığını daha fazla ön plana almasının etkisi araştırmanın bu bulgusunu anlaşılır kılmaktadır.

Ayrıca sosyal beceri yeteneği yakın ilişkiler kurma, ikna becerisi gibi faydaları içinde barındırsa bile bu yetenekler bireyin kendi ihtiyaç ve hislerini dengelemezse bireye zarar veren bir süreç haline gelebilmektedir (Goleman, 2017, s.165). Bu doğrultuda birey duygusal zekâsının kişisel ve kişilerarası boyutlarında denge sağlayamadığında hem sosyal hem de bireysel anlamda bireyin kendisine zarar gösterme ihtimali ortaya çımaktadır. Öz kontrolün ve duygusallığın bireyde fazla olması bireyin sosyal iyi oluşunu olumsuz etkileyebilir. Bu gibi etkenlerin var olması toplam duygusal zekâ puanı, duygusallık ve öz kontrol alt boyutları ile sosyal iyi olmanın negatif yönde ilişki içinde olması sonucunun anlamlandırılmasında etkili olabilmektedir. 


\section{Sonuç}

Yapılan bu araştırmada üniversite öğrencilerinin ruminatif düşünme biçimlerinin duygusal zekâ düzeyleri ile negatif yönde anlamlı bir ilişkisi olduğu, ayrıca duygusal zekanın sosyallik ve duygusallık alt boyutları ile düşük düzeyde anlamlı bir ilişkisi varken öz kontrol alt boyutu ile negatif düşük düzeyde bir ilişkisi olduğu görülmektedir. Ayrıca üniversite öğrencilerinin sosyal iyi olma düzeylerinin duygusal zekâ düzeyleri ile ilişkisinin de negatif yönde anlamlı olduğu görülmektedir. Araştırmadan elde edilen bu bulgular ışığında aşağıdaki önerilere yer verilmiştir:

1. Araştırma bulgularına göre kadınların ruminatif düşünme biçimi puanlarının erkeklere göre daha yüksektir. Kadınlardan oluşan gruplara yönelik tekrarlayıcı zorlayıcı düşüncelerin bileşenlerini tanımaya yönelik çalışmalar yapılabilir.

2. Yapılan araştırmada algılanan anne baba tutumu otoriter ve koruyucu olanların ruminatif düşünme biçimi puanlarının algılanan anne baba tutumu demokratik olanlara göre daha fazla olduğu bulunmuştur. Bu bağlamda tekrarlayıcı zorlayıcı düşüncelerin önüne geçilebilmesi için bu tutumlardan ziyade demokratik tutumu geliştirmek amacıyla aile eğitimleri düzenlenebilir.

3. Öğrencilerin akademik anlamda kendilerini başarılı olarak algılamaları ve böylelikle iyi oluşlarının sağlanması için mesleki rehberlik kapsamında uygulanan kariyer danışmanlığında öğrencilerin ilgi, yetenek ve değerlerine göre yönlendirmeler yapılabilir.

4. Duygusal zekâ geliştirilebilen bir zekâ türü olması sebebiyle bireylerin tüm gelişim dönemi boyunca ilgili zekâ türünü geliştirmeye yönelik psiko-eğitimler uygulanabilir.

Öğrencilere verilen eğitimde akademik odaklı olmanın yanı sıra ruhsal olarak sağlıklı bireyler yetişmesi önemli bir husustur. Bu yüzden duygusal zekâ ve sosyal iyi olma konularında öğrencinin gelişmesi ve bu becerileri dengeli bir şekilde kullanabilmesi için sosyal beceri eğitimi, duygusal zekâ, farkındalık, kendini tanıma, problem çözme, toplum bilincinin gelişimi gibi konuları barındıran eğitimler yapılmalıdır. 


\title{
EXTENDED ABSTRACT
}

\section{The Relationship Between Ruminative Thought Style and Social Well Being Level of the University Students with the Emotional Intelligence}

\author{
Zeynep Lale - Fikret Gülaçt1 \\ Erzincan High School , Erzincan Binali Yıldırım University
}

This research was intended to examine the relationship levels of ruminative ways of thinking and social well-being of university students with emotional intelligence. According to Goleman (2017, p.62) emotional intelligence is "self-actualization, to be able to move on though setbacks, to delay satisfaction by controlling impulses, to be able to regulate mood, not to let adversity hinder thinking, to be able to put oneself in someone else's place and to have hope".

Emotional intelligence has been studied in four sub-dimensions by Petrides and Furnham (2001) as subjective well-being, self-control, sentimentality and sociability.

The basic dimensions of emotional intelligence is divided to two as ability and hybrid models. Bar-On Model, Goleman model, Cooper and Sawaf model is under mixed model

While the Mayer and Salovey model is within the Talent Model.

According to Keyes (1998); social well-being forms a basis for a universal definition of a social example of being good.

Social well-being is the evaluation of individual's situation and handling of the social process. Keyes ' model of social well - being conceptualizes the social aspect of well-being. It is dealt with in five dimensions showing the degree to which individuals function in social life. Keyes ' (1998) model includes social acceptance, social realization, social contribution, and social cohesion.

To solve the existing problems of the individual does not take action in the past stuck in repetitive thoughts about the possible causes and consequences of the emotions in which they are found are defined as the concept of rumination (Nolen-Hoeksema, 1987). 
Rumination - oriented theories are divided into the theory of reaction forms, the theory of purposeful progress, rumination about sadness, rumination in response to stress, and the theory of self-regulating executive functions.

The research was conducted from general screening models to relational screening models. As a Research Group sampling technique, cluster sampling technique was used. This research conducted in 7 different faculties in the 2017-2018 academic year (Economics and Administrative) Faculty Of Sciences, Faculty Of Education, Faculty Of Arts And Sciences, Faculty Of Theology, Faculty of Law, Faculty of Engineering, Faculty of Pharmacy) and constitutes of 11,257 undergraduate students. A sample group of 670 people from the research universe was selected from easily accessible ones. Of these students, 244 were male (36.4\%) and 426 (63.6\%) were female.

Personal information form, emotional intelligence trait-short form, social well-being scale and ruminative thinking style scale were used in this study. Personal information form

consists of a total of 6 questions. Information about gender, age, faculty, perceived income level of parents, perceived attitudes of parents, and current academic achievement of the students are available.

Trait Emotional Intelligence Questionnaire-Short Form: Emotional Intelligence Feature Scale-Short Form was developed by Petrides and Furnham (2000, 2001). It is a scale whose validity and reliability had been previously proven and was adapted to Turkish by M. Engin Deniz, Esin Ozer ,Erkan Isik (2013) .It has a four factor structure consisting of 20 items. These four factors are "subjective well-being", "self-control", "sensuality" and "sociality.. It is a 7-point likert type scale. While " 1 " expresses "I strongly disagree; "7" expresses "Strongly Agree".

Social Well-being Scale: It's a scale, which was developed by Keyes, (1998) to measure the social well-being of the participants, was adapted to Turkish by Akın, Demirci, Çitemel, Sarıçam and Ocakçı (2013, May). The scale consists of 15 items and a 7-point Likert-type scale is used. In this scale "1" means "Strongly Disagree" and "7" means "Strongly Agree".

Ruminative Thought Style Questionnaire: The original name was "Ruminative Thought Style Questionnaire R (RTSQ). It was developed by Jay K. 
Brinker and David J.A. Dozois in 2009 and adapted to Turkish by Hasan Turan Karatepe (2010). It consists of 20 items and 7 point likert scale type is used. In this likert scale, " 1 " is defined as "none" and "7" is defined as "very good".

Depending on the variables in the analysis of research data ; Kruskal Wallis Test, Mann Whitney U, Spearman Correlation Analysis were performed by using SPSS package program

As a result of the study, ruminative thought style score showed significant difference according to gender, perceived income level, perceived parental attitude, on the other hand it showed no significant difference according to perceived academic success. It was found that there was no significant difference in terms of gender, perceived income level and perceived academic success in social well- being of university students in comparison with perceived parental attitude. It was found that total emotional intelligence score did not showed difference according to gender, perceived income level, perceived academic achievement and perceived parental attitude. In addition, among the ruminative thought styles and social wellbeing with emotional intelligence have seen a significant relationship in the negative direction.

In the light of these findings, the following suggestions are given:

1. According to the findings of the study, women's ruminative thinking style scores are higher than men's. Studies can be conducted to recognize the components of repetitive coercive thoughts for groups of women.

2. In order to prevent repetitive compelling thoughts, family trainings can be organized in order to develop democratic attitude.

3. In order to ensure that the students perceive themselves as successful in academic terms and thus to be well, guidance can be made according to their interests, abilities and values of the career counseling applied within the scope of vocational guidance.

4. As the emotional intelligence is a type of intelligence that can be developed, psycho-training can be applied to develop the type of intelligence during the whole development period of individuals.

In addition to being academically oriented, it is an important issue to educate mentally healthy individuals. Therefore, in order to improve students' emotional intelligence and social well-being, to reduce ruminative thoughts, 
to use these skills in a balanced way, trainings such as social skills training, emotional intelligence, awareness, self-knowledge, problem solving, community awareness should be applied .

\section{Kaynakça / References}

Akın, A., Demirci, İ., Çitemel, N., Sarıçam, H. ve Ocakçı, H.(2013). Sosyal iyi olma ölçeği Türkçe formu'nun geçerlik ve güvenirliği. 5. Ulusal Lisansüstü Eğitim Sempozyumu, 10-11, Sakarya.

Alloy, L. B., Abramson, L. Y., Hogan, M. E., Whitehouse, W. G., Rose, D. T., Robinson, M. S.,..., Lapkın, J. B.(2000). The temple-wisconsin cognitive vulnerability to depression project: Lifetime history of axis 1 psychopathology in individuals at high and low cognitive risk for depression. Journal of Abnormal Psychology, 109(3), 403-418.

Baer, R. A.(2015).Mutluluk uygulamaları. (K. Ertaş, Çev.), İstanbul: Olimpos Yayınları.

Buluş M.(1997). Üniversite öğrencilerinde yalnızlık. Pamukkale Üniversitesi Eğitim Fakültesi Dergisi, 3(3), 82-90.

Butler L. D. ve Nolen-Hoeksema, S.(1994). Gender differences in response to depressed mood in a college sample. Sex roles, 30, 331-346.

Carver, C. S. ve Scheier, M. F.(1990). Origins and functions of positive and negative affect: a control-process view. Psychological Review, 97(1), 19-35.

Cenkseven Önder, F. ve Utkan, Ç.(2018). Bilinçli farkındalık ve algılanan stres ilişkisinde ruminasyon ve olumsuz duygu düzenlemenin aracı rolü. Mersin University Journal of the Faculty of Education, 14(3), 10041019.

Çetinkaya, B.(2016). Çocuk ruh sağ lı̆̆ı. Ankara: Pegem Akademi.

Çetinkaya, T.(2017). Duygusal zekâ yeteneğinin ilk ve ortaokul yöneticilerinin başarı düzeyleri üzerindeki etkisini belirlemeye yönelik bir uygulama. Yayınlanmamış yüksek lisans tezi, Avrasya Üniversitesi, Trabzon.

Deniz, M. E., Özer, E. ve Işık, E. (2013). Duygusal zekâ özelliği ölçeği-Kısa formu (TEIQue-SF) Geçerlik ve güvenirlik çalışması. Eğitim ve Bilim, 38(169), 407-419.

Diener, E.(1984). Subjective well-being. Psychological bulletin, 95(3), 542-575.

Diener, E. ve Diener, C.(1996). Most people are happy. American Psychological Society, $7(3), 181-185$. 
Diener E. (2000). Subjective well-being: The science of happiness and a proposal for a national index. American psychologist, 55(1), 34-43.

Doğan, S. ve Şahin, F.(2007). Duygusal zekâ: tarihsel gelişimi ve örgütler için önemine kavramsal bir bakış. Çukurova Üniversitesi Sosyal Bilimler Enstitüsü Dergisi, 16(1), 231-252.

Dönmezer, İ.(1999). Ailede iletişim ve etkileşim. İstanbul: Sistem Yayıncılık.

Erguvan-Eryılmaz, T. ve Tosun, A.(2013). Obsesif kompulsif bozuklukta kontrol ihtiyac1. Anadolu Üniversitesi Sosyal Bilimler Dergisi, 13(1), 121-130.

Goleman, D. (2017). Duygusal zekâ neden IQ'dan önemlidir? (Çev. B. S. Yüksel). İstanbul: Varlık Yayınları.

İnci, S.(2014). Aday öğretmenlerin duygusal zekâ ile yaşam doyumu düzeyleri arasındaki ilişki. Yayınlanmamış yüksek lisans tezi, Çanakkale: 18 Mart Üniversitesi.

Karasar, N.(2016). Bilimsel araştırma yöntemi. 30.Bsm, Ankara: Nobel Akademik Yayıncilik.

Karatepe, H. T.(2010). Ruminatif düşünme biçimi ölçeğinin Türkçe'ye uyarlaması, geçerlik ve güvenirlik çalışması. Yayımlanmamış Psikiyatri Uzmanlık Tezi, İstanbul: Bakırköy Prof. Dr. Mazhar Osman Ruh Sağlığı ve Sinir Hastalıkları Eğitim ve Araştırma Hastanesi 13. Psikiyatri Kliniği.

Keyes, C. L. M.(1998). Social well-being. Social Psychology Quarterly, 61(2), 121-140.

Köksal, O., Dilci, T. ve Koç, M.(2013). Çocuklarda görülen sosyal problemlerin akademik başarıya etkisi üzerine öğretmen görüşlerinin incelenmesi. Electronic Turkish Studies, 8(8), 873-883.

Luminet, O.(2004). Measurement of depressive rumination and associated construct. In (P. Costas, ve A. WellsEd.), Depressive Rumination Nature, Theory and Treatment (p.187-217), England: Wiley.

Martin L. ve Tesser A.(1996). Some ruminative thought., In (R.S. Wyer Ed.), Ruminative thoughts, advances in social cognition (p.1-47), Hillsdale: Erlbaum.

Matthews, G. ve Wells, A.(2004). Rumination, depression, and metacognition: the s-ref model. In (P. Costas, ve A. Wells Ed.). Depressive rumination nature, theory and treatment (p.125-151), England: Wiley.

Nolen-Hoeksema, S.(1987). Sex differences in unipolar depression: Evidence and theory. Psychological bulletin, 101(2), 259-282. 
Nolen-Hoeksema, S. ve Jackson, B.(2001). Mediators of the gender difference in rumination. Psychology of Women Quarterly, 25(1), 37-47.

Nolen-Hoeksema, S.(2004). The response styles theory. In (P. Costas, ve A. Wells Ed.), Depressive rumination nature, theory and treatment (p.107123), England: Wiley.

Petrıdes, K. V. ve Furnham, A. (2001). Trait emotional intelligence: Psychometric investigation with reference to established trait taxonomies, European Journal of Personality, 15(6), 425-448.

Şanal-Karahan, F.(2016). Üniversite öğrencilerinde çözüm odakl düşünmenin depresyon, anksiyete, stres ve psikolojik iyi oluş ile ilişkisi. Yayınlanmamış doktora tezi. Konya: Necmettin Erbakan Üniversitesi.

Talavera D. C., Paulus D. J., Garza M., Ochoa-Perez M., Lemaire C., Valdivieso J. ,..., ve Zvolensky M. J.(2018). Subjective social status and rumination in relation to anxiety and depressive symptoms and psychopathology among economically disadvantaged latinos in primary care. American Journal of Orthopsychiatry, 88(2), 169-179.

Ulutaş, İ. (2005). Anasınıfına devam eden altı yaş çocuklarının duygusal zekâlarına duygusal zekâ eğitiminin etkisinin incelenmesi. Yayımlanmamış Doktora Tezi. Gazi Üniversitesi, Ankara.

Yavuzer, H.(1998). Yaygin ana- baba tutumları. (H. Yavuzer, Ed.), Ana Baba Okulu içinde (s.115-133), İstanbul: Remzi Kitabevi

\section{Kaynakça Bilgisi / Citation Information}

Lale, Z. ve Gülaçtı, F. (2020). Üniversite öğrencilerinin ruminatif düşünme biçimlerinin ve sosyal iyi olma düzeylerinin duygusal zekâ düzeyleri ile ilişkisi. OPUS-Uluslararası Toplum Araştırmaları Dergisi, 14(20), 201-231. DOI: 10.26466/opus.568178 